\title{
Application of Biotic Indices and Pollution Tolerance Index in Assessing Macro-Invertebrate Assemblage of Ediba River, Cross River State, Nigeria
}

\author{
Andem AB ${ }^{1}$, Esenowo $\mathrm{IK}^{2^{*}}$ and Bassey $\mathrm{DO}^{1}$ \\ ${ }^{1}$ Department of Zoology and Environmental Biology, University of Calabar, Calabar, C.R.S, Nigeria \\ ${ }^{2}$ Department of Zoology, University of Uyo, Akwa Ibom State, Nigeria
}

\begin{abstract}
The study of the macro-invertebrates community of Ediba River in Cross River State was carried out from October to December, 2014 using Pollution Tolerance Index (PTI). Macro-invertebrate fauna were sampled with sweeping net using kick sampling methods. Sixteen genera, belonging to nine orders and a total of 289 individuals were encountered. The dominant groups in the order were Oligochaeta $(29.1 \%)>$ Diptera (24.62\%)>Odonata (20.3\%), showing insignificant difference between the three stations at $p>0.05$. Taxa richness was highest in Station 1 (2.985) and least in Station 3 (1.008) showing insignificant differences across station ( $p>0.05$ ). Evenness ranges from 0.337 to 0.369 showing significant difference across stations $(p<0.05)$. Station 1 had a PTI value of 39 indicating good quality water status, while Stations 2 and Station 3 had PTI values of 6 and 4 respectively indicating poor quality water status. The abundance of pollution tolerance species of the orders, Odonata Zygoptera, Oligochaeta, Diptera and the absence of pollution sensitive species of the orders, Ephemeroptera and Trichoptera in Stations 2 and 3 indicated the poor waters quality, coupled with the low PTI values in both stations, hence need for proper management of the river.
\end{abstract}

Keywords: Bio-assessment; Biotic indices; Macro-invertebrate; Pollution tolerance index

\section{Introduction}

Macro-invertebrates communities are widely used as indicators of river ecosystem health status because they include a wide range of species, each with relatively well- known sensitivity or tolerance to river conditions [1]. They are useful in understanding the ecological health of an aquatic ecosystem, rather than using chemical and microbiological data, which at least give short-term fluctuations [2]. Macro-invertebrates are considered important because they reflect the cumulative effects of the present and past conditions; also they have low mobility (i.e. are sessile or nearly) and life cycles of several weeks or years [3]. Benthic invertebrates range in sizes from $0.2 \mathrm{~mm}$ to $15 \mathrm{~cm}$ in length as in the case of a fully grown fresh water crayfish, while most are larvae of insects, others are aquatic snails and worms [4].

Bio-monitoring studies and the use of macro-invertebrates to rate the quality of water bodies of both lotic and lentic types have been widely reviewed elsewhere $[5,6]$. The use of pollution tolerance index (PTI) as a method of measuring the overall health status of aquatic bodies through the use of macro-invertebrates remains the most reliable and effective method [7-9]. Macro-invertebrates which are utilized in aquatic pollution studies include: Mayflies (Ephemeroptera), caddisflies (Trichoptera), stoneflies (Plecoptera), beetles (Coleoptera), crayfish and amphipods (Crustaceans), aquatic snails (Mollusca), biting midges (Chironomids) and leeches (Hirudinea) [10-12]. This study is undertaken to investigate the composition, abundance and distribution of macro-invertebrate community and using pollution tolerance index to assess the health status of Ediba River.

\section{Materials and Methods}

\section{Study area}

The Ediba River in Abi Local Government Area of Cross River State, Nigeria is located in latitude $05^{\circ} 52^{\prime \prime} 49.7^{\prime \prime} \mathrm{N}$ and longitude $07^{\circ}$ $59^{\prime} 56.7 \mathrm{E}^{\prime \prime}$ (start point) and latitude $05^{\circ} 53^{\prime} 29.0^{\prime \prime} \mathrm{N}$ and longitude $07^{\circ}$ $58^{\prime} 41.3$ " E (end point) (Figure 1). The river is the second largest of Southern Nigeria, with a width of 1000 yards during flood. It reaches its greatest depth in September - October with an average of $30 \mathrm{ft}$ at the bank. The river is subjected to various anthropogenic activities. Three sampling stations were selected using geographical positioning system (GPS) and base on effluent discharge, land use patterns, human impacts, solid wastes disposal and bank type.

Station 1 lies in latitude $05^{\circ} 52^{\prime} 49.7^{\prime \prime} \mathrm{N}$ and longitude $08^{\circ} 00^{\prime}$ 06.9" $\mathrm{E}$. The bank of the river is inundated with herbs, shrubs and trees. Activities are very minimal in this area except fishing which is predominant. Station 2 lies in latitude $05^{\circ} 52^{\prime} 22.3^{\prime \prime} \mathrm{N}$ and longitude $07^{\circ}$ 59' 44.7E. Aquatic macrophytes such as (Lemna pausicostata) dominated the area. There were also shrubs and human droppings and Cattle dung associated with this area. Station 3 lies in latitude $05^{\circ} 51^{\prime} 48.0^{\prime \prime} \mathrm{N}$ and longitude $\left.07^{\circ} 59^{\prime} 32.7^{\prime \prime} \mathrm{E}\right)$. The station is dominated by shrubs and herbs and characterized with human activities such as sewage discharge.

\section{Collection of macro-invertebrates}

Sampling of macro-invertebrates was carried out during the hours of 8:00 am to 12:00 pm. Macro-invertebrate samples were collected from three (3) sampling stations with sweeping net using kick sampling methods. The sediments collected were poured into a polythene bag and taken to the laboratory for analysis. The sediments were passed through 3 sieves of $2 \mathrm{~mm}, 1 \mathrm{~mm}$ and $0.5 \mathrm{~mm}$ mesh sizes to collect the macro-invertebrates. The macro-invertebrates were poured into a white enamel tray, stained with Rose Benger solution and sorted using

*Corresponding author: Esenowo IK, Department of Zoology, University of Uyo, Akwa Ibom State, Nigeria, Tel: 2348036671097; E-mail: imehesenowo@yahoo.com

Received June 03, 2015; Accepted July 22, 2015; Published July 26, 2015

Citation: Andem AB, Esenowo IK, Bassey DO (2015) Application of Biotic Indices and Pollution Tolerance Index in Assessing Macro-Invertebrate Assemblage of Ediba River, Cross River State, Nigeria. J Environ Anal Toxicol S7: 007. doi:10.4172/2161-0525.S7-007

Copyright: (C) 2015 Andem AB, et al. This is an open-access article distributed under the terms of the Creative Commons Attribution License, which permits unrestricted use, distribution, and reproduction in any medium, provided the original author and source are credited. 


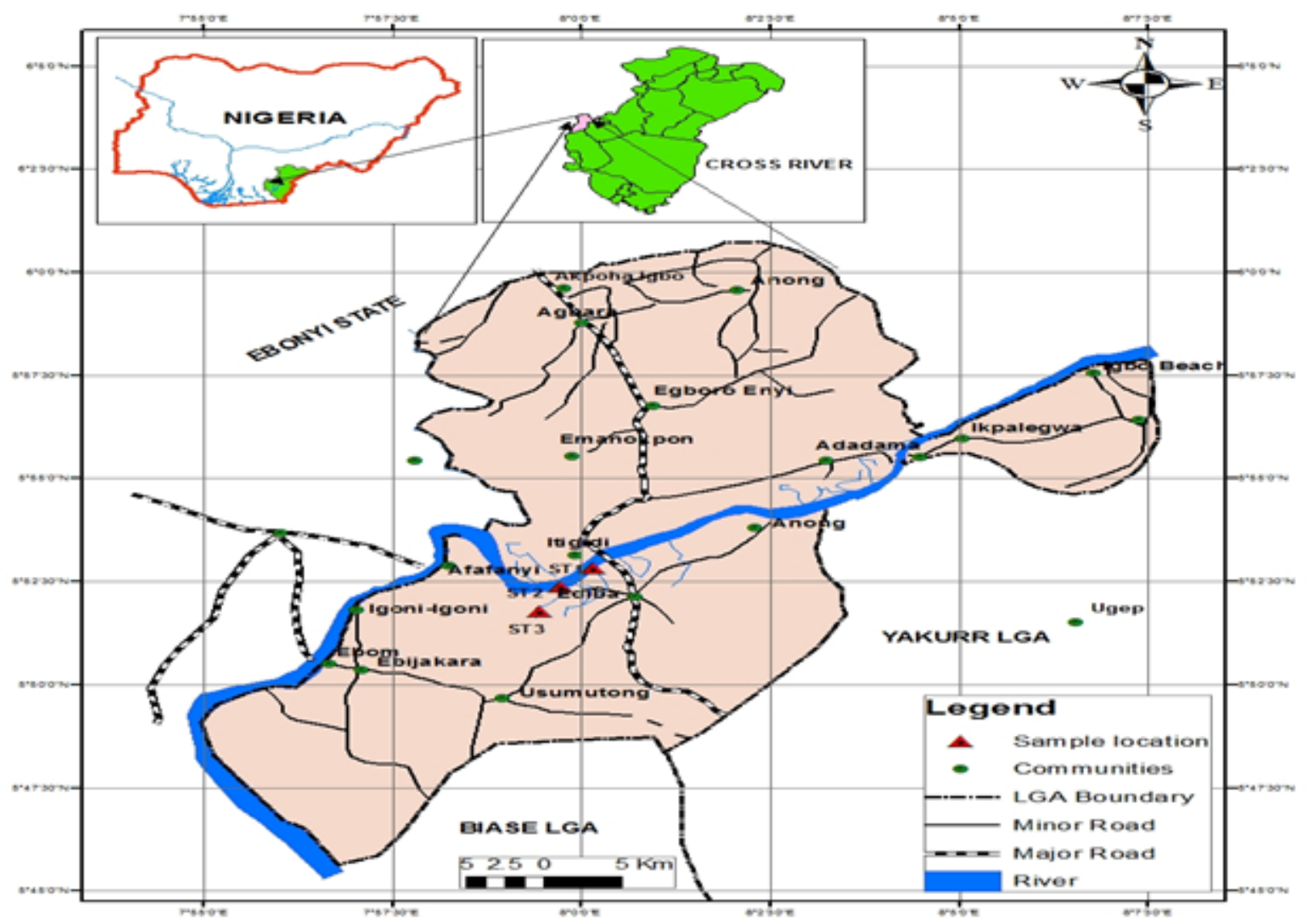

Figure 1: Map of study area showing the sampling stations.

forceps into different groups and preserved in $4 \%$ Formalin. Then, they were identified and counted, using standard keys according to [13-16].

\section{Statistical analysis}

Statistical data were subjected to analysis of variance (ANOVA) to compare the differences in species composition and abundance with Microsoft Word Excel 2007. Biological indices, such as taxa richness, evenness (E) and Shannon-Weiner diversity, were determined using version 3 of PAST Software Design.

\section{Determination of Pollution Tolerance Index (PTI)}

Pollution tolerance Index (PTI) was determined by utilizing the methods $[17,18]$. Three groups of macro-invertebrates were assigned a multiplication factor of 3 for the pollution sensitive group (Ephemeroptera, Trichoptera and Plecoptera), 2 to the facultative tolerant group (Anisoptera, Zygoptera and Decapoda) and 1 to the pollution tolerant group (Gastropods, Oligochaetes and Hirudinea). Values obtained were thereafter compared with established standard values in accordance with [7].

\section{Results}

A total of sixteen genera belonging to nine orders and 289 individuals were encountered. The relative abundance of macroinvertebrates taxa encountered at the different sampling stations is presented in Table 1, while Table 2 shows the percentage composition of macro-invertebrate taxa in the Ediba River.

\section{Diversity Indices}

The diversity index for the three Stations is shown in Table 3. Taxa richness or Margalef's index (d) was highest in Station 1 (2.985) and lowest in Station 3 (1.008). Station 1 had the highest diversity index value of 0.947 , while, Station 3 recorded the lowest diversity index value of 0.604 . Evenness ranges from 0.337 in Station 3 to 0.362 in Station 2. Margalef s index (d) and Shannon wieners show insignificant difference across station $(p>0.05)$ while evenness show significant difference across stations $(\mathrm{p}<0.05)$.

\section{Pollution Tolerance Index (PTI)}

PTI was utilized to assess the overall health status of the study area and to ascertain the extent of human impact on the river is shown in Table 4. Unpolluted water would have values between 23 and above as excellent, 17 - 22 as good, while the polluted water would have $11-16$ as fair and $<10$ as poor. The PTI values for Stations 2 and 3 were 6 and 4 respectively indicating a poor water quality status.

\section{Discussion}

The abundance of macro-invertebrates encountered in the study area was generally low. Ephemeroptera and Zygoptera were poorly represented accounting for $0.82 \%$ and $1.44 \%$ respectively of the relative abundance [6] reported high diversity of Ephemeroptera which includes Ademophleboides sp., Baetis sp., Centroptillum sp., Cloeon sp., Cloeon bellum and Ephemerella ignita in Edion and Omodo Rivers in Southern 
Citation: Andem AB, Esenowo IK, Bassey DO (2015) Application of Biotic Indices and Pollution Tolerance Index in Assessing Macro-Invertebrate Assemblage of Ediba River, Cross River State, Nigeria. J Environ Anal Toxicol S7: 007. doi:10.4172/2161-0525.S7-007

Page 3 of 9

\begin{tabular}{|c|c|c|c|c|c|c|c|c|}
\hline Taxanomic & $\mathbf{S}_{1}$ & $\%$ & $\mathrm{~S}_{2}$ & $\%$ & $\mathrm{~S}_{3}$ & $\%$ & Total & $\%$ \\
\hline \multicolumn{9}{|l|}{ ARTHROPODA } \\
\hline \multicolumn{9}{|l|}{ INSECTA ODONATA } \\
\hline Trithemis arteriosa & 1 & 2.18 & - & 0 & - & 0 & 1 & 0.72 \\
\hline Crocothermis erythra & 14 & 30.4 & - & 0 & _- & 0 & 14 & 10.13 \\
\hline Palpopleura pleura & 7 & 15.2 & - & 0 & 2 & 2.6 & 9 & 8.73 \\
\hline Macromia sp. & 1 & 2.18 & - & 0 & - & 0 & 1 & 0.72 \\
\hline \multicolumn{9}{|l|}{ HEMIPTERA } \\
\hline Hydrometria sp. & 4 & 8.7 & _- & 0 & _- & 0 & 4 & 2.9 \\
\hline Physopella sp. & 2 & 4.34 & - & 0 & - & 0 & 2 & 1.44 \\
\hline \multicolumn{9}{|l|}{ TRICHOPTERA } \\
\hline Hydoptila sp. & 2 & 3.57 & - & 0 & - & 0 & 2 & 1.19 \\
\hline Limnophilus sp. & 3 & 5.35 & _- & 0 & - & 0 & 3 & 1.78 \\
\hline \multicolumn{9}{|l|}{ DIPTRERA } \\
\hline Helius sp. & 13 & 28.2 & 10 & 12.3 & - & 0 & 23 & 13.5 \\
\hline Anopheles sp. & - & 0.00 & 10 & 12.3 & 11 & 14.2 & 21 & 8.83 \\
\hline Palpamyia sp. & 2 & 4.34 & 1 & 1.23 & 1 & 1.3 & 4 & 2.29 \\
\hline \multicolumn{9}{|l|}{ ZYGOPTERA } \\
\hline Coenagrion sp. & 2 & 4.34 & - & 0 & - & 0 & 2 & 1.44 \\
\hline \multicolumn{9}{|l|}{ EPHEMEROPTERA } \\
\hline Lanista Africana & 2 & 2.46 & _- & 0 & - & 0 & 2 & 0.82 \\
\hline \multicolumn{9}{|l|}{ DECAPODA } \\
\hline Macrobrachium vollenhovenii & 3 & 23.0 & 17 & 17.8 & 8 & 5.55 & 28 & 15.45 \\
\hline \multicolumn{9}{|l|}{ ANNELIDS } \\
\hline \multicolumn{9}{|l|}{ POLYCHAETES } \\
\hline Capitella $s p$ & - & 0 & 16 & 19.7 & 63 & 81.8 & 79 & 12.8 \\
\hline \multicolumn{9}{|l|}{ OLIGOCHAETES } \\
\hline Tubifex sp. & - & 0 & 41 & 50.6 & 53 & 36.8 & 94 & 29.1 \\
\hline No.of species & 13 & & 6 & & 6 & & 16 & \\
\hline No.of Individuals & 56 & 23.2 & 95 & 6.31 & 144 & 5.55 & 289 & 100 \\
\hline & & \multirow{2}{*}{ ANOVA } & & & $\mathbf{F}$ & FCrit & P-value & Inference \\
\hline & & & & & 6.94 & 7.79 & 0.06 & $P>0.05(N S)$ \\
\hline
\end{tabular}

Where $\mathrm{S}_{1}=$ Ruhura Station, $\mathrm{S}_{2}=$ Itumudea Station, $\mathrm{S}_{3}=$ Enoe Station

Table 1: Relative Abundance and Composition of macro-invertebrate communities encountered in Ediba River 
Citation: Andem AB, Esenowo IK, Bassey DO (2015) Application of Biotic Indices and Pollution Tolerance Index in Assessing Macro-Invertebrate Assemblage of Ediba River, Cross River State, Nigeria. J Environ Anal Toxicol S7: 007. doi:10.4172/2161-0525.S7-007

Page 4 of 9

\begin{tabular}{|c|c|c|}
\hline Taxa Groups & $\mathbf{( \% )}$ & No. of Individuals \\
\hline Odonata & 20.3 & 25 \\
\hline Hemiptera & 4.34 & 6 \\
\hline Zygoptera & 1.44 & 2 \\
\hline Diptera & 24.62 & 48 \\
\hline Ephemeroptera & 0.82 & 2 \\
\hline Trichoptera & 2.97 & 5 \\
\hline Polychaetes & 12.8 & 79 \\
\hline Oligochaetes & 29.1 & \\
\hline Decapoda & 15.45 & \\
\hline Total & & 28 \\
\hline
\end{tabular}

Table 2: Percentage composition and Taxonomic Groups including, the dominant and subdominant in the Ediba River.

\begin{tabular}{|l|c|c|c|}
\hline Biotic Indices & $\mathbf{S}_{1}$ & $\mathbf{S}_{2}$ & S $_{3}$ \\
\hline Taxa richness(d) & 2.985 & 1.098 & 1.008 \\
\hline Shannon weiner (H) & 0.947 & 0.648 & 0.604 \\
\hline Evenness (E) & 0.369 & 0.362 & 0.337 \\
\hline
\end{tabular}

Where $S=$ indicates significant difference at a probability level less than $5 \%,(P<0.05)$

NS $=$ indicates not significant difference at a probability level greater than $5 \%(P>0.05)$

Where $\mathrm{S}_{1}=$ Ruhura Station, $\mathrm{S}_{2}=$ Itumudea Station, $\mathrm{S}_{3}=$ Enoe Station

Table 3: Diversity of the macro-invertebrate community of Ediba River.

\begin{tabular}{|l|c|c|c|}
\hline STATIONS & PTI & $\begin{array}{c}\text { WATER QUALITY } \\
\text { STATUS }\end{array}$ & Excellent \\
\hline Ruhura & 39 & Poor & RATING \\
\hline Itumudea & 6 & Poor & $<10$ \\
\hline Enoe & 4 & $<10$ \\
\hline
\end{tabular}

Table 4: Summary of the overall health status of the water quality in Ediba River.

Nigeria and the high abundance of these species is an indication of good water quality. Odonata are known to be facultative species as they are mostly associated with moderately polluted waters and this order was well represented, with the highest diversity of species encountered during the study period. The diversity of Odonata was encountered in Station 1 with species such as; Trithermis arteriosa, Crocothemis erythra, Palpopleura pleura and Macromia sp. None were recorded in Station 2 and only Palpopleura pleura in Station 3. The high abundance of Odonata in Station 1 maybe due to food availability or habitat preference of this species [19] also reported high abundance of Odonata in Awba Reservoir in Ibadan, Oyo State. Diptera was the second largest taxa after Oligochaetes in relative abundance. Three species of Helius sp., Anopheles sp. and Palpamyia sp. were encountered. Helius sp. was encountered in Stations 1 and 2, with 13 and 10 species respectively. Anopheles sp., was not recorded in Station 1, but occurred in Stations 2 and 3, with 10 and 11 species respectively. The relative abundance of these taxa has been reported by [20] who showed that conditions such as substrates and the alkaline $\mathrm{pH}$ of the water body have favoured their abundance. Lower number of Trichoptera (Caddis fly) was recorded, accounting for $2.97 \%$ of the relative abundance. According to [21] the larva of caddis fly does not tolerate polluted water, hence the lower number in this study. Hemiptera were fairly represented with two species (Hydrometria sp. and Physopella malanoptera), while only one species each of Oligochaetes and Polychaetes were represented (Tubifex sp., and Capitella sp,). Oligochaetes and Polychaetes were completely absent in Station 1, but present in Stations 2 and 3, with 53 and 94 individuals respectively. This may be due to the fact that Annelids are mostly pollution tolerant species and can survive wide range of pollution in water [20-23] recorded several species of Oligochaetes in Warri River including Nais sp. and this was due to the richness of the immediate substrate in organic matter, their feeding habits as they are deposit feeders, their tolerance to silting, decomposition and flow rate than other macrobenthic groups. Among the Decapoda, only one species of fresh water prawn was encountered (Macrobrachium vollenhovenii). A high pollution tolerance index of 39 was recorded for Station 1, where organisms, such as Ephemeroptera and Trichoptera, were encountered, which indicates Oligosaprobic in quality. However, Odonata, Decapoda and Oligochaetes were high in Stations 2 and Station 3, indicating that the waters were relatively polluted or mesosaprobic in quality. The relatively low diversities of Ephemeroptera and Trichoptera as encountered in this study may be due to habitat preference. Trichoptera are mostly present in upland streams or rivers which are well oxygenated when compared to low land fresh waters as encountered in this study.

\section{Conclusion}

Pollution sensitive taxa such as Ephemeroptera and Trichoptera were completely absent in Stations 2 and 3 indicating the poor quality status and the low PTI values in this stations. The need for long-term hydro-biological investigation, with elaborate emphasis on water quality monitoring and the ecology of macro-invertebrate fauna is so much recommended for the safety and conservative use of Ediba River and other fresh water bodies and their resources.

\section{References}

1. Esenowo IK, Ugwunba AAA (2010) Composition and abundance of Macrobenthes in Majidun River Ikorodu Lagos State. Nigeria. Research Journals of Biological Science 5: 556-560

2. George AD, Abowei JF, Alfdared-Ockiya JF (2009). The Distribution, Abundance and Seasonality of Benthic Macro-invertebrate in Okpoka Creek Sediment, Niger Delta, Nigeria. Resource Journal of Applied Science and Engineer Technology 2: 11-18

3. Adakole JA, Anunne PA (2003) Benthic macroinvertebrates as indicators of environmental quality of an urban stream, Zaria, Northern, Nigeria. $\mathrm{J}$ Aquat Sc 18: 85-92. 
Citation: Andem AB, Esenowo IK, Bassey DO (2015) Application of Biotic Indices and Pollution Tolerance Index in Assessing Macro-Invertebrate Assemblage of Ediba River, Cross River State, Nigeria. J Environ Anal Toxicol S7: 007. doi:10.4172/2161-0525.S7-007

Page 5 of 9

4. Lawa AR (2013) Macro-invertebrate Tolerance Value and Assemblage Tolerance Index (ATI) For Western USA Streams and Rivers. Journal of the North American Benthological Society 29: 852-866.

5. Odiete WO (1999) Environmental physiology of animals and pollution. Diversified Resources, Lagos, Nigeria 220-246.

6. Olomukoro OJ, Dirisu RA (2012) Macro-invertebrate Community and Pollution Tolerance Index in Edion and Omodo Rivers in Derived Savannah Wetlands in Southern Nigeria: Jordan Journal of Biological Science 7:19-24.

7. Bonada N, Prat N, Resh VH, Statz-ner B (2006) Developments in aquatic insect biomonitoring: a comparative analysis of recent approaches. Annu Rev Entomol 51: 495-523.

8. Omoigberale MO, Ogbeibu AE (2010) Environmental Impacts of Oil Exploration and Production on the Invertebrate fauna of Osse River, Southern Nigeria. Resource Journal of Environmental Science 4: 101-114.

9. Cheimonopoulou MT, Bobori DC, Theocharopoulos I, Lazaridou M (2011) Assessing ecological water quality with Macroinvertebrates and fish: a case study from a small Mediterranean River. Environmental Management 47: 279290.

10. Victor R, Ogbeibu AE (1985) Macro benthic Invertebrates of a Stream flowing through Farmland in Southern Nigeria. Environmental Pollution 39: 339-349.

11. Ikomi RB, Arimoro FO, Odihirin OK (2005) Composition, distribution and abundance of macro invertebrates of the upper reaches of River Ethiope, Delta State, Nigeria. Zoologist 3: 68-81.

12. Oku EE, Andem AB, Arong BG, Odjadjare E (2014) Effect of Water Quality on the Distribution of Aquatic Entomofauna of Great Kwa River, Southern Nigeria. American Journal of Engineering Research 3: 265-270.

13. Macan TT (1959) A guide to Freshwater invertebrate animals. Longman, England 118
14. Pennak RW (1978) Freshwater invertebrates of the United States. (2 $2^{\text {nd }}$ Edn) John Wiley and Sons, New York 810.

15. Edmunds J, Agyei-Henaku D (1978) Sea Shells and other Molluscs found on West African Coast and Estuaries. Ghana University Press, Accra pp 146.

16. WHO (1978) A Field Guide to African Freshwater Snails. WHO Snail Identification Center, Danish Bilharziasis Lab. Jaegersborg, Charlottenlund Denmark pp 30.

17. Klemm DJ, Philip AL, Florence L (1990) Macro-invertebrate Field and Laboratory Method for Evaluating the Biology Integrity of Surface Water United State Environmental Protection Agency 256.

18. Izaak Walton League of American (IWLA) (1994) Creek Connection Aquatic Life Module. Aquatic Macro-invertebrate Sampling. Adapted from Volunteer Stream Monitoring Methods Manual, United States Environmental Protection Agency, Office of Water, Draft Document EPA 841-B-97-003.

19. Popoola KOK, Otalekor A (2011) Analysis of Aquatic Insects' Communities of Awba Reservoir and its Physico-Chemical Properties. Research Journal of Environmental and Earth Sciences 3: 422-428.

20. WallaceRB, Hynes HBN (1981) The Effect of Chemical Treatment against Black fly Larvae on the Fauna of Running waters. In: Laird M (Eds), Black Flies, the Future for Biological Methods in Integrated Control, Academic Press London 237-258.

21. Silby J (2001) Dragon flies of the world. Natural History Museum in Association with CSIRO publishing, UK and Europe 122-127.

22. Olomukoro JO (1996) Macrobenthic fauna of Warri River in Delta State Nigeria. (Ph.D Thesis) University of Benin, Benin City, Nigeria 205pp.

23. Atobatele EO, Ugwumba AAA (2005) Physical chemical and faunal characteristics of a southern Nigeria reservoir. Zoologist 3: 15-25.
This article was originally published in a special issue, Toxicology \& Environmental Safety handled by Editor(s). Dr. Abdel-Tawab H. Mossa, National Research Centre, Egypt 